\title{
La globalización: el olvido del dolor del mundo
}

\author{
Iñaki Marieta
}

Pero a nosotros, poetas, corresponde estar con la cabeza desnuda bajo las tormentas de Dios.

Hölderlin

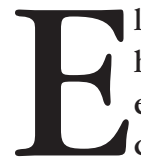

1 proceso planetario que tiene lugar en todos los ámbitos de la actividad humana, y que denominamos "globalización", no obedece al azar. No es simplemente consecuencia del enorme avance de las telecomunicaciones y de la informática ocurrido durante y después de la Segunda Guerra Mundial, ${ }^{1}$ tampoco se debe al hundimiento de la Unión Soviética y la caída del muro de Berlín, ni siquiera a que Reagan y Thatcher en la década de los ochenta del siglo pasado pusieran en marcha el modelo neoliberal de mercado en el que prospera la actual globalización. ${ }^{2}$ Todos estos y muchos otros elementos están sin duda en la base del despliegue óntico-planetario en que consiste la globalización: el poder de una humanidad capaz de estar presente en todos los rincones del planeta, e incluso más allá, gestionando gracias a las telecomunicaciones sus más diversos intereses con el fin aparente de mejorar la calidad de la vida humana. Pero esto es sólo la descripción de lo que ocurre a la vista de todos vinculado a las triunfantes ciencias matemáticas que en su des-esencialización ${ }^{3}$ se han adueñado del imaginario epistémico del planeta como nunca antes había ocurrido. ${ }^{4}$

\section{Parménides y la globalización como destino}

Si la globalización no obedece al azar, eso significa que ya estaba ocurriendo y preparándose para un futuro que nunca habría de llegar; si es cierto que

${ }^{1}$ Vid. George Dyson, La catedral de Turing. Los orígenes del universo digital. Trad. de F. J. Ramos Mena. Barcelona, Debate, 2015.

${ }^{2}$ David Murillo, De Walmart a Al Qaeda. Una lectura interdisciplinar de la globalización. Barcelona, Libros de Cabecera, 2015, pp. 205-206.

${ }^{3}$ Martin Heidegger, La pregunta por la cosa. Trad., notas y glosario de J. M. Gómez del Valle. Gerona, Palamedes, 2009, pp. 97 y ss.

${ }^{4}$ Vid. D. Murillo, op. cit. 
hemos asistido al fin de la historia..$^{5}$ De modo que dicho proceso globalizador constituye todo el presente en su doble sentido, temporal y presencial, en la medida en que su despliegue actual obedece a un destino enunciado originalmente por Parménides en su Poema, mediante uno de los nombres con

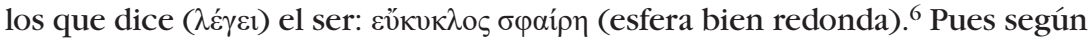
Heidegger en su conferencia de 1951, "Logos":

[...] el hecho de que en la época griega el ser del ente se haya convertido en lo digno de ser pensado es el comienzo de Occidente, es la fuente oculta de su sino. Si este comienzo no guardara lo sido, es decir, la coligación de lo que todavía mora y perdura, ahora no prevalecería el ser del ente desde la esencia de la técnica de la época moderna. Por esta esencia, hoy en día todo el globo terráqueo es transformado y conformado en vistas al ser experienciado por Occidente, el ser representado en la forma de la verdad de la metafísica europea y de la ciencia. ${ }^{7}$

Lo que en palabras de su urbanizador hermenéutico, Gadamer, ${ }^{8}$ significa que "es un destino y no la historia (recordada y comprensible) lo que comenzará con el pensamiento ontológico de la metafísica griega y que llevó el olvido del ser a su extremo en la ciencia y la técnica modernas".?

Desde entonces nuestro destino greco-occidental está vinculado a una comprensión del ser cuya perfecta esfericidad, pues no sólo es $\sigma \varphi \alpha i ́ p \eta$ sino

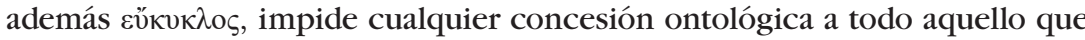
pase por no ser esferizable. En especial, según Parménides, "los mortales

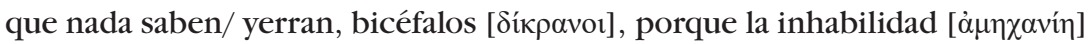
en sus/ pechos dirige su mente errante". ${ }^{10}$

${ }^{5}$ Ibid., p. 101. Cf. Francis Fukuyama, El fin de la historia y el último hombre. Trad. de P. Elías. Barcelona, Planeta, 1992.

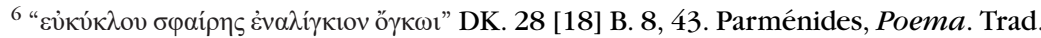
de A. Gómez Lobo. Buenos Aires, Charcas, 1985, fr. 8, v. 43.

${ }^{7}$ M. Heidegger, "Logos", en Conferencias y artículos. Trad. de E. Barjau. Barcelona, Serbal, 2001, p. 168.

${ }^{8}$ La expresión es de Jürgen Habermas en su escrito de 1979 ("Hans-Georg Gadamer. Urbanización de la provincia heideggeriana", en Perfiles filosófico-políticos. Trad. de M. Jiménez Redondo. Madrid, Taurus, 2000, p. 346).

${ }^{9}$ Hans-Georg Gadamer, Los caminos de Heidegger. Trad. de A. Ackermann Pilári. Barcelona, Herder, 2002, p. 75 y Jean Beaufret, Dialogue avec Heidegger: philosophie grecque. París, Minuit, 1974, p. 9.

${ }^{10}$ Parménides, op. cit., fr. 6, vv. 4-6. 
Si el ser, según la descripción de Parménides en el fragmento 8 del Poe$m a,{ }^{11}$ se agota en una esfera bien redonda, lo no esférico no puede ser. ${ }^{12}$ Resultando de ello que la esfericidad como imagen remite a la univocidad de sentido en la que se agota el ser según el eléata desde la perspectiva aristoté-

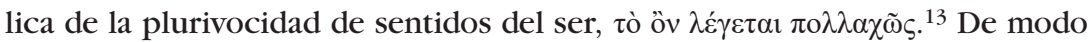
que lo devenido, lo cambiante, lo sujeto a generación y corrupción, no puede aspirar a la identidad/mismidad constitutiva de lo permanente y que remite propiamente al estatuto ontológico de lo que es en cuanto que es, pues la inestabilidad congénita de aquel le niega el carácter esférico que necesariamente corresponde al ser lo que es.

\section{Crítica a la univocidad del ser en Parménides y su mantenimiento en el marco metafísico de la idea platónica y de la ousía aristotélica}

Contra esta tiránica y unívoca comprensión del ser, y por boca del Extranjero, quien se considera "una especie de parricida $[\pi \alpha \tau \rho \alpha \lambda o i ́ \alpha \nu]$ ", por tener que "poner a prueba lo que dice mi padre Parménides, y [...] forzarlo defendiendo que el no ser, en cierto modo, es, y, por el contrario, que el ser no existe de cierta manera", ${ }^{14}$ Platón logra en El sofista refutar la tesis de Parménides y

11 "Además, puesto que hay un límite extremo, está completo/ desde toda dirección, semejante a la masa de una esfera bien redonda,/ igualmente equilibrada desde el centro en toda dirección; pues no es correcto/ que sea algo más grande ni algo más débil aquí o allá./ Pues no existe algo que no sea que le impediría llegar/ a su semejante, ni existe algo que sea de modo que/ de lo que es, haya aquí más y allá menos, porque es del todo inviolable./ Por ende, siendo igual desde toda dirección, alcanza uniformemente sus límites" (Parménides, op. cit., fr. 8, vv. 42-49).

${ }^{12}$ Dimensión modal que recoge el fragmento 2 del Poema cuando la diosa le relata al viajero, exhortándole a que preserve "el relato después de escucharlo/ cuáles son las únicas vías de investigación que son pensables:/ Una, que es y que no es posible que no sea,/ es la senda de la persuasión, pues acompaña a la verdad./ La otra, que no es y que es necesario que no sea,/ ésta, te lo señalo, es un sendero que nada informa/ pues no podrías conocer lo que, por cierto, no es (porque no es factible)/ ni podrías mostrarlo" (Parménides, op. cit., fr. 2, vv. 1-8). Para esta cuestión en particular, así como para todo lo relativo al Poema de Parménides (texto griego, traducción inglesa y francesa, ensayos críticos, problemas de interpretación): Pierre Aubenque, dir., Études sur Parménide. París, Vrin, 1987, t. I, pp. 180 y ss. Vid. Alejandro Llano, "Modalidades", en Metafísica y lenguaje. Pamplona, Universidad de Navarra/Eunsa, 2011, cap. IV.

${ }^{13}$ Aristóteles, Metafísica. Ed. trilingüe de V. García Yebra. Madrid, Gredos, 1982, VII 1, 1028a 10.

${ }^{14}$ Platón, El sofista. Trad. de A. Tovar y R. P. Binda. Madrid, Instituciones de Estudios Políticos, 1970, 241d-e. 
de sus discípulos los megáricos, ${ }^{15}$ mostrando la existencia de ese no ser relativo que es lo Otro. ${ }^{16}$ Aristóteles, por su parte, encuentra una solución al problema ontológico que plantea la tesis parmenídea de la univocidad del ser, en la distinción de sus múltiples sentidos que de alguna manera desbloquea la comprensión esfericista del eléata, aun cuando la multiplicidad de sentidos del

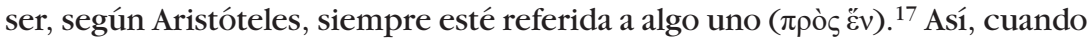
la esfera primordial abandone su divina univocidad para compartir el ámbito del sentido con la pluralidad de los otros, reduciendo con ello su perfección totalizante, no por ello deja de estar presente como la unidad vinculante de sentido para lo no esférico, para lo otro que oủoía.

\section{La globalización como esfera bien redonda}

Es evidente que toda esta tradición, la nuestra, que comienza con Parménides

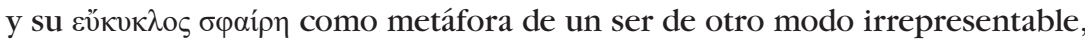
tiene su inicio en esta comprensión-imagen del ser en la que nos encontramos siendo y fuera de la cual, no puede haber "nada". Y esto es así porque el origen, como casi todo lo importante y decisivo, es ambiguo. ${ }^{18}$ También es el caso del participio őv del verbo cĩval. ${ }^{19}$ Pues según Heidegger, "el comienzo [Beginn] es aquello con lo que algo empieza [anhebt]; el inicio [Anfang] aquello de

${ }^{15}$ La crítica de Aristóteles a los megáricos en el capítulo 3 del libro Ix de la Metafísica,

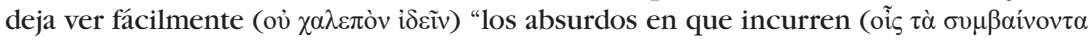

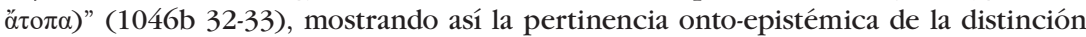
potencia/acto sin la cual el ámbito de lo físico, de lo en movimiento (Física, III 1, 200b 12-15), queda anulado epistemológica y ontológicamente, como también ocurre en

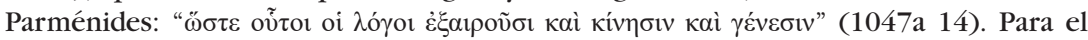
eléata sólo lo que es y no es posible que no sea, acompaña a la verdad (B2 3-4), pues ser y pensar es lo mismo (B3); lo cambiante, que propiamente no es, pues lo que es en cuanto que es, no puede cambiar ni devenir, queda relegado al ámbito de los díkpavot y de las opiniones que les caracterizan (B6). En palabras de Llano, "los megáricos tenían una concepción demasiado angosta -unívoca- de la realidad" (A. Llano, op. cit., p. 268).

${ }^{16}$ P. Aubenque, Le problème de l'être chez Aristote. París, PUF, 1962, pp. 146-148.

${ }^{17}$ Aristóteles, Metafísica, IV 2, 1003a 33-34. Vid. M. Heidegger, "Sección introductoria”, en La pregunta por la cosa.

${ }^{18}$ M. Heidegger, ¿Qué significa pensar? Trad. de R. Gabás. Madrid, Trotta, 2005, p. 168. "Toda forma esencial del espíritu (jede wesentliche Gestalt des Geistes) se encuentra en la ambigüedad (Zweideutigkeit)" (M. Heidegger, Introducción a la metafísica. Trad. de A. Ackermann Pilári. Barcelona, Gedisa, 2003, p. 18).

${ }^{19}$ En relación con la cuestión del "protagonismo" del participio del verbo ser en el surgimiento de la filosofía, véase Iñaki Marieta, "El inicio de la problemática ontológica en el comienzo de la filosofía", en Isegoría. Revista de Filosofía Moral y Política, núm. 51, julio-diciembre, 2014, pp. 709-728. 
lo que algo surge [entspringt]", y sustituyendo la Primera Guerra Mundial, que es como sigue el texto de Heidegger, por la globalización, el texto diría que "la globalización se inició hace cientos de años en la historia espiritual y política de Occidente" ${ }^{20}$ Este inicio destinal de la globalización demuestra que el proceso en el que consiste no obedece al azar, ni es mera consecuencia del desarrollo de las ciencias matemáticas, las telecomunicaciones y la informática, sino que hay algo decisivo ( sentido, si se me permite la expresión, a través de las telecomunicaciones y de la informática que hoy experimentamos a nivel planetario y que denominamos latinamente globalización, le fue ya revelada al viajero del "Proemio" del Poema de Parménides por una diosa, como la verdad en cuyo cumplimiento venimos trabajando desde hace siglos, habida cuenta de las transformaciones tecnológicas ocurridas de entonces a ahora. ${ }^{21}$

\section{La globalización como gigantismo, el gigantismo como nihilismo y la dimensión metafísica de la globalización con base en su gigantismo}

Heidegger en La época de la imagen del mundo (1938), tildará el cumplimiento del destino esférico del ser, en lo que tiene de metafísico, de gigantismo. Y haciendo gala de lo que hoy sería una total inocencia e ingenuidad tecnológicas, escribe lo siguiente:

Una señal que evidencia este proceso es que en todas partes aparece lo gigantesco [das Riesenhafte] bajo las formas y disfraces más diversos. [...] Lo gigantesco [das Riesige] se afirma bajo una forma que precisamente parece hacerlo desaparecer: en la aniquilación [Vernichtung] de las grandes distancias gracias al avión, en la representación en toda su cotidianidad, producida a placer y sin ningún esfuerzo, de mundos

${ }^{20}$ M. Heidegger, Hölderlins Hymnen "Germanien" und "Der Rhein", en Felix Duque, Los buenos europeos. Hacia una filosofía de la Europa contemporánea. Oviedo, Nobel, 2003, p. 69, n. 28.

21 "La diosa me acogió con afecto y tomando mi diestra en la suya/ se dirigió a mí y me habló de esta manera:/ Oh, joven, compañero de inmortales aurigas,/ tú que con las yeguas que te llevan alcanzas hasta nuestra casa,/ isalud! Pues no es un mal hado el que te ha inducido a seguir/ este camino -que está, por cierto, fuera del transitar de los hombres-,/ sino el Derecho y la Justicia. Es justo que lo aprendas todo,/ tanto el corazón imperturbable de la persuasiva verdad/ como las opiniones de los mortales, en las cuales no hay creencia verdadera./ No obstante aprenderás también esto: como las apariencias/ habrían tenido que existir genuinamente, siendo en todo (momento) la totalidad de las cosas" (Parménides, "Proemio", en Poema, vv. 22-32). 
extraños y lejanos gracias a la radio. Pero creer que lo gigantesco [das Riesige] es simplemente el vacío extendido hasta el infinito de lo que sólo es cuantitativo, es pensar de manera demasiado superficial. [...] Lo gigantesco [das Riesige] es más bien aquello por medio de lo cual lo cuantitativo se convierte en una cualidad propia y, por lo tanto, en una manera especialmente señalada de lo grande. ${ }^{22}$

Que la globalización es algo gigante en cuanto a su implantación planetaria es evidente, ${ }^{23}$ pero lo que no lo es tanto es que ese gigantismo propio de la globalización por donde se mostrará su dimensión metafísica, tiene la capacidad de aniquilar (vernichten), de convertir en nada (Nichts) el espacio y el tiempo, por cuanto que las distancias ya no son nada para los aparatos supersónicos que las recorren, y el tiempo de transmisión o de recepción de un mensaje se ha convertido en lo que se denomina "en tiempo real", es decir, presente absoluto. Ahora bien, esta capacidad aniquiladora (vernichtende) propia del gigantismo que caracteriza a la globalización, hunde sus raíces en el suelo tecnológico que la alimenta, que no es sino la metafísica.

La globalización queda así vinculada al nihilismo por su condición gigantesca, es decir, por su capacidad aniquiladora propia del nihilismo consumado en que se agota la metafísica. De este modo la globalización no es sino el cumplimiento de un olvido que el propio Parménides activó ${ }^{24}$ al pensar el

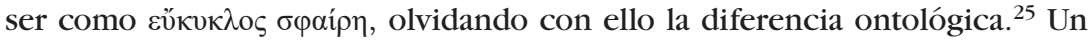

${ }^{22}$ M. Heidegger, "La época de la imagen del mundo", en Caminos de bosque. Trad. de H. Cortés y A. Leyte. Madrid, Alianza, 2010, pp. 77-78.

23 "Lo correcto constata cada vez algo que es lo adecuado en lo que está delante. Sin embargo, para ser correcta, la constatación no necesita en absoluto desvelar en su esencia lo que está delante. Sólo allí donde se da este desvelar acaece de un modo propio lo verdadero" (M. Heidegger, "La pregunta por la técnica", en Conferencias y artículos, p. 10).

24 "[...] no encontramos en ningún lugar semejante experiencia del ser mismo. En ningún lugar nos sale al encuentro un pensar que piense la verdad del ser mismo y, por tanto, la propia verdad en cuanto ser. Incluso allí, donde el pensamiento preplatónico prepara el despliegue de la metafísica por medio de Platón y Aristóteles, en su calidad

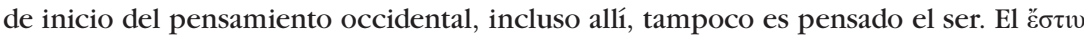

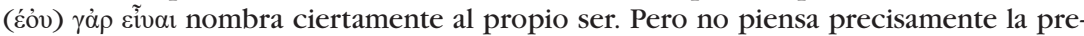
sencia como presencia a partir de su verdad. La historia [Geschichte] del ser comienza [beginnt], y además necesariamente, con el olvido del ser" (M. Heidegger, "La frase de Nietzsche 'Dios ha muerto'”, en Caminos de bosque, p. 195).

25 "Heidegger admite que el olvido del ser comenzó a partir de los presocráticos, en particular con Parménides, quien, con su tesis de la identidad del ser y el pensar, se halla en el origen del idealismo moderno" (P. Aubenque, ¿Hay que desconstruir la metafísica? Madrid, Encuentro, 2012, pp. 65 y 100). Cf. D. Parenteau, Du recours heideggerien à la thèse ontologique de Parménide: sur la différence ontologique comme 
olvido que con Platón ${ }^{26}$ dará inicio a la metafísica, ese "mal destino del ser [das böse Geschick des Seins]", dice Heidegger, originado por "la caída del pensar en las ciencias y la fe". ${ }^{27}$ Así, desde el inicio (Anfang) griego, el pensar de la metafísica, que no es "una palabra primordial [Urwort]" ${ }^{28}$ sino el "título para un problema": ${ }^{29}$

\section{[...] no se deja involucrar por el ser mismo porque ya ha pensado el ser, lo ha pensado como ente, en la medida en que éste, el ente, es. El ser mismo permanece impensado en la metafísica por una necesi- dad esencial. La metafísica es la historia en la que del ser mismo no hay esencialmente nada: la metafísica es, en cuanto tal, el nihilismo propio. $^{30}$}

Esta realización de la metafísica, como nihilismo propio, inaugura la época de la metafísica consumada en la que ser en cuanto tal ya no queda nada, y parafraseando a Nietzsche, diremos que no sólo el desierto crece sino que ya

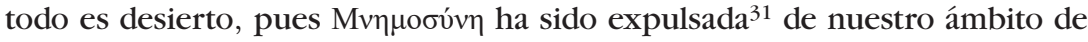
experiencia. Una época, la nuestra, en la que el olvido del ser como olvido del

le fait originaire, 2004, en http://id.erudit.org/iderudit/801262ar. La tesis contraria cuya genealogía se remonta a J. Beaufret ("Lecture de Parménide", en Dialogue avec Heidegger. Philosophie grecque. París, Minuit, 1973), la sostiene Françoise Dastur, en Philosophie et Différence. París, Les Éditions de La Transparence, 2004, n. 13. Lo curioso en este asunto es que ambas tesis tienen su origen en Heidegger. Lo que plantea la pregunta ¿de cuántos Heidegger-es estamos hablando?

26 "La 'filosofía', que comienza sólo a partir de Platón, tiene desde ese momento el carácter de lo que más tarde se llamará 'metafísica'" (M. Heidegger, "La doctrina platónica de la verdad", en Hitos. Trad. de H. Cortés y A. Leyte. Madrid, Alianza, 2000, p. 196). "La métaphysique comme pensée représentative dont le premier germe se trouve dans l'idea platonicienne qui instaure la primauté du voir sur l'apparaître et qui s'accomplit comme certitude et savoir absolu de soi avec Descartes et Hegel." (F. Dastur, Heidegger et la pensée à venir. París, Vrin, 2011, p. 25).

${ }^{27}$ M. Heidegger, "La sentencia de Anaximandro", en Caminos de bosque. p. 262.

28 "La palabra 'metafísica', para decirlo primero negativamente, no es una palabra primordial [Urwort]. Por palabra primordial entendemos una palabra que se ha formado a partir de una experiencia humana esencial y original como su expresión. En ello no es necesario que esta palabra primordial haya surgido también en un tiempo primigenio: puede ser relativamente tardía" (M. Heidegger, Los conceptos fundamentales de la metafísica. Mundo, finitud, soledad. Trad. de A. Ciria. Madrid, Alianza, 2007 p. 50).

${ }^{29}$ Ibid., p. 84 .

${ }^{30}$ M. Heidegger, Nietzsche. Trad. de J. L. Vermal. Barcelona, Destino, 2000, t. II, p. 285.

31 "La desertización es el rápido curso de la expulsión [Vertreibung] de Mnemosine" (M. Heidegger, ¿Qué significa pensar?, p. 28). 
misterio ${ }^{32}$ que debería dar que pensar ${ }^{33}$ se nos muestra a cada momento en el triunfal despliegue tecnológico que vincula necesariamente la globalización y la metafísica, puesto que "la esencia de la técnica [...] se identifica con el concepto de la metafísica que se está consumando [vollendenden] ". ${ }^{34}$

\section{Dignidad y tragedia}

Lo trágico de esta situación y por lo que el proceso en que consiste la globalización alcanza la categoría de destino (Geschick), es que, según Heidegger, "la Metafísica [...] es una única fatalidad (Verhängnis: horizonte inevitable), pero quizás también la fatalidad necesaria de Occidente y el presupuesto de su dominio planetario". 35

Si la globalización puede entenderse como un triunfo del ente en su despliegue tecno-científico en pos del dominio del planeta y por qué no, del universo, lo es a pesar del propósito humano que pretende dirigirlo, de ahí su condición trágica, en la medida en cuanto metafísica, la globalización, escribe Heidegger, "deja las cosas del hombre suspendidas en medio del ente, sin que el ser del ente [das Sein des Seienden] pueda jamás ser experienciado, interrogad y ensamblado en su verdad como el pliegue [als die Zwiefalt] de ambos [...]" 36

Uno de los resultados de todo esto, el más visible al menos para la mirada que no olvida el misterio del ser, es, según Heidegger:

La uniformidad [die Gleichförmigkeit] de la marcha de la historia de la época actual [...] uniformidad del ente que surge del vacío del abandono del Ser, una uniformidad en la que lo único que importa es la seguridad calculable del ordenamiento del ente, [...] Como la realidad consiste en la uniformidad de la cuenta planificable, también el hombre, para estar a la altura de lo real, tiene que entrar en esta uniformidad [Einförmigkeit $].^{37}$

La memoria, como Nietzsche decía del arte, no es más que una defensa para no perecer ante la verdad. La verdad simple e inmediata en que consiste

32 "En la contemplación de este refugio que se cobija a sí mismo, de la propia esencia, tal vez toquemos la esencia del misterio bajo cuya forma se presenta la verdad del ser" (M. Heidegger, "La frase de Nietzsche 'Dios ha muerto'”, en op. cit., p. 196).

33 "Lo que más merece pensarse en nuestro tiempo problemático es el hecho de que no pensamos" (M. Heidegger, ¿Qué significa pensar?, p. 17).

${ }^{34}$ M. Heidegger, "Superación de la metafísica", en Conferencias y artículos, p. 72.

${ }^{35}$ Ibid., p. 56.

${ }^{36}$ Idem.

${ }^{37}$ Ibid., p. 71. 
el dolor. Un dolor presente y activo en cada individuo que somos, y que por eso, por creer que duele por ser, quiere olvidar el ser. Pero olvidamos el ser sin nuestro consentimiento y ésa es, quizás, la máxima fuente de dolor. Aunque la esperanza en un nuevo inicio no puede abandonarnos, la situación presente es en ese sentido desesperante. Al menos esta situación nos pone en el estado de preguntar: "la piedad del pensar [die Frömmigkeit des Denkens]", ${ }^{38}$ según Heidegger. Primer paso para experimentar una sacralidad en la que lo divino encuentre de nuevo un ecosistema propicio en el que la existencia no esté abocada al desencanto productivista, fruto del totalitarismo tecno-científico.

Pero cada vez con más intensidad la fuente de luz que es el triunfo neo-liberal de la globalización tecno-científica para la que ya no cuentan las ideologías, convirtiéndose ella en la Gran Ideología como falsa conciencia socialmente necesaria, oscurece más y mejor los vertederos del planeta donde miles de seres humanos rebuscan en la basura los restos de un reparto a todas luces injusto y en el que el olvido del ser tiene su patencia más pestilente. ¿Cómo es posible que ya no ocurra, pues para eso está "el dominio de la voluntad" bajo el cual al hombre le "está vedada la esencia del dolor, del mismo modo [que] la esencia de la alegría" ${ }^{39}$ si no que no se le busque solución para mantener la dignidad que como humanos debiera ser lo primero que nos pre-ocupa compartir? Pues la indignidad de un individuo pone en cuestión la valía de la dignidad del resto.

En este momento es imprescindible traer a colación al maestro Paul Ricoeur y su Sí mismo como otro, donde entre otros muchos conceptos clave está el de solicitud, gracias al cual el concepto de dignidad alcanza un nivel de reciprocidad implicativa sin la cual se puede quedar en mero orgullo despectivo por el débil:

Pues del otro que sufre procede un dar que no bebe precisamente en su poder de obrar y de existir, sino en su debilidad misma. Quizá ahí reside la prueba suprema de la solicitud: que la desigualdad de poder venga a ser compensada por una auténtica reciprocidad en el intercambio [...] Lo que la solicitud añade es la dimensión de valor que hace que cada persona sea irremplazable en nuestro afecto y en nuestra estima. ${ }^{40}$

Además de la bondad y nobleza que emanan de las palabras de Ricoeur, hay un sentido ontológico en ellas sin el cual la dignidad necesaria que hace la

${ }^{38}$ M. Heidegger, "La pregunta por la técnica", en Conferencias y artículos, p. 32.

${ }^{39}$ M. Heidegger, "Superación de la metafísica", en op. cit., p. 73.

${ }^{40}$ Paul Ricoeur, Sí mismo como otro. Trad. de A. Neira y M. C. Alas de Tolivar. Madrid, Siglo XXI, 1996, pp. 198-201. 
humanidad de lo humano quedaría condicionada por resultados que responden a contingencias de las que los humanos no somos responsables. Aunque haya doctrinas filosóficas que pretenden imponer al hombre un determinismo que, en la mayoría de los casos, sólo consigue hacer de él un ser cruel y violento con los otros. Quienes pueden deben poder también por los que no pueden. Y aunque este comportamiento no puede exigirse como un imperativo, sí debe poder hacer que cada individuo, en su confrontación con esa exigencia, decida cómo vivir su dignidad: autísticamente o solícitamente. La cuestión ético-jurídica, que se plantea en este punto, es que a partir de aquí nada ni nadie parece poder obligarnos en una u otra dirección: la autística o la solícita. La libertad no puede ser impuesta en una supuesta buena dirección porque entonces dejaría de serlo.

En ese sentido, el olvido del ser que nos incumbe inevitablemente en nuestra condición de herederos de una tradición que además, hemos hecho nuestra de manera eminente, es también, cómo no, el olvido del dolor del mundo, que no podemos ocultar tras las deslumbrantes candilejas de la conexión global que ha triunfado sobre el tiempo y el espacio. Porque en la diferencia, en lo que difiere, se está señalando a la fuente misma del dolor. Su reconocimiento colorido en los diferentes no es más que un avatar de la metafísica insuperable. ${ }^{41}$ Pues según Heidegger, la "superación de la metafísica" (Überwindung der Metaphysik) no margina a la metafísica. Mientras el hombre siga siendo el animal rationale, también es el animal metaphysicum. ${ }^{42}$ En ese sentido: "El pensar sólo comienza cuando hemos experimentado que la razón, tan glorificada durante siglos, es la más tenaz adversaria del pensar". ${ }^{43}$

Sólo atreviéndonos a entrar en la diferencia, protegidos por la actitud piadosa del que pregunta (das Fragen ist die Frömmigkeit des Denkens) tenemos alguna posibilidad de soportar el dolor del mundo e iniciar la transformación contra su olvido. Y aun ahí, en el pliegue (in der Zwiefalt), sólo podemos, momentáneamente, en el tiempo de la memoria, intentar desactivar un olvido cuya dimensión trágica nos convierte en héroes que invocando a la dignidad saben que van a perecer en el intento.

41 "Dado que la metafísica sólo podemos superarla cuando se realiza en ella la experiencia del olvido del ser, es decir, cuando se llega hasta las últimas consecuencias de la interpretación del ser a partir del ente y de la presencia, la gran exigencia de nuestra época consiste en emprender el retorno a la experiencia originaria de las primeras tematizaciones ontológicas, pues únicamente de este modo es posible sacar a la luz el modo deteriorado y cristalizado en que la tradición encubre lo trasmitido por ella, abriendo, al mismo tiempo, nuevas posibilidades reflexivas fuera de los dominios del pensamiento calculador" (Ángel Xolocotzi et al., Heidegger, del sentido a la historia. Madrid, Plaza y Valdés, 2014, p. 116).

${ }^{42}$ M. Heidegger, "Introducción a ‘QQué es la metafísica?”, en Hitos, p. 301.

${ }^{43}$ M. Heidegger, "La frase de Nietzsche "Dios ha muerto", en op. cit., p. 198. 
Schelling, ${ }^{44}$ el filósofo de lo trágico, ${ }^{45}$ fue quien en su carta décima sobre dogmatismo y criticismo da cuenta filosófica de la tragicidad de lo trágico, en

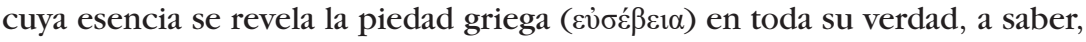
aquello que en el drama trágico debe sobrevivir a toda finitud: la dignidad humana. Ésa es, al menos, una posible lectura de las últimas líneas de ese segundo párrafo memorable. "Fue un gran pensamiento el de cargar voluntariamente con la pena por un crimen inevitable [unvermeidliches] para así, por la pérdida de la libertad misma, demostrar precisamente esa libertad, y perecer todavía con una declaración de voluntad libre [mit einer Erklärung des freien Willens]". ${ }^{46}$

La tragedia griega entendió aquello que es lo más valioso para el hombre y que por tanto hay que preservarlo duela lo que duela. ${ }^{47}$ En ese sentido la tragedia griega es una respuesta digna al desconsuelo de saberse mortal para quienes no esperan nada del más allá. ${ }^{48}$ Pues sin la dignidad, la libertad con la que combatir lo inevitable está falta de lo que ennoblece un acto que de otra manera podría pasar por simple desesperación. La dignidad es lo que dota de nobleza al ser humano. Y ningún noble puede permitir que en su entorno se cometan actos innobles.

Lo que ocurre con la globalización en su aniquilación del espacio y del tiempo, pues en eso consiste el nihilismo que la vincula con la metafísica, es que se pierde el entorno ( $\tilde{\eta} \theta 0 \varsigma$ ). Ya no tenemos un ámbito ético, un entorno de comportamiento próximo en el que la falta de dignidad nos increpe personalmente y necesitemos restaurarla dando así paso a la pura actividad política.

${ }^{44} C f$. Martin Thibodea, Hegel et la tragédie grecque. Rennes, PUR, 2011.

45 "Desde Aristóteles se cuenta con una poética de la tragedia, [pero] con una filosofía de lo trágico no se cuenta sino desde Schelling" (Peter Szondi, Tentativa sobre lo trágico. Trad. de J. Orduña. Madrid, Dykinson, 2011, p. 245).

${ }^{46} \mathrm{~F}$. W. J. Schelling, Cartas filosóficas sobre dogmatismo y criticismo. Ed. bilingüe de E. Maraguat. Madrid, Abada, 2009, pp. 200-201.

${ }^{47}$ Es Hölderlin pensador de lo trágico, quien en sus "Anotaciones sobre Edipo", escribe lo siguiente, "La presentación de lo trágico se basa principalmente en que lo monstruoso de la manera en que el dios y el hombre se aparean y el poder de la naturaleza y lo más íntimo del hombre se tornan en la cólera de manera ilimitada una única y misma cosa, se concibe justamente porque ese ilimitado volverse uno se purifica mediante una ilimitada escisión" (Edipo. Sófocles/Hölderlin. Trad. de H. Cortés y M. E. Prado. Madrid, La Oficina, 2012, p. 358). Para el comentario de este enigmático texto, véase $\mathrm{Ph}$. Lacou-Labarthe, La poesía como experiencia. Trad. de J. F. Megías. Madrid, Arena, 2006, p. 35.

${ }^{48}$ El canto XI de la Odisea es el documento literario donde mejor se lee ese horror de la muerte que poseía a los griegos del relato de Homero. Donde alcanza su culmen es en las palabras del héroe Aquiles cuando se dirige a Ulises en estos términos: "No pretendas, Ulises preclaro, buscarme consuelos/ de la muerte, que yo más querría ser siervo en el campo/ de cualquier labrador sin caudal y de corta despensa/ que reinar 
En ese sentido, escribe Heidegger: "el "mundo" [Welt] se ha convertido en inmundo [Unwelt] [...] En la época del poder exclusivo del poder, es decir, del acoso incondicionado del ente para el consumo en la usura, el mundo se ha convertido en in-mundo [ist die Welt zur Unwelt geworden], en la medida en que el Ser, si bien esencia, lo hace sin su propio prevalecimiento [Walten]". ${ }^{4}$

¿Cómo darle la vuelta a esta situación? ¿Cómo salir de la insuperable metafísica? ¿Cómo acabar con el olvido del ser constitutivo de nuestro destino occidental y global? ¿Cómo hacer para que la visibilidad cotidiana del dolor del mundo no sea su propia pantalla en la que se opaca su esencia permitiéndonos asistir narcotizados al espectáculo mediático en el que se representa la función continua de la indignidad humana? El tono pesimista de estas preguntas sólo lo es para una expectativa optimista y hasta dialéctica de lo que podemos. Es decir, para un planteamiento que en ningún momento se pregunta por la esencia del poder, en la medida en que se considera satisfecho con esta conexión global que "con paciencia y con tiempo" llegará a todos los rincones del planeta, realizando así el sueño de la globalización como aniquilación del espacio-tiempo. En ese sentido, Heidegger escribe en un tono aparentemente pesimista:

Ninguna mera acción va a cambiar el estado del mundo, porque el Ser, como eficacia y actividad efectiva, cierra el ente al acaecimiento propio. Ni siquiera el inmenso dolor [das ungeheure Leid] que pasa por la tierra es capaz de despertar de un modo inmediato cambio alguno, porque se lo experiencia sólo como dolor, y éste es un modo pasivo y por ello como contraestado de la acción [als Gegenzustand zur Aktion] [... $]^{50}$

El olvido del dolor del mundo se enraiza en una comprensión pasiva del dolor, meramente óntica, y aunque no por ello falsa, sí insuficiente para propiciar el cambio que lograría hacer visible, esencialmente, y no sólo espectacularmente, el dolor del mundo. Y es que, escribe Heidegger:

El dolor del que primero hay que hacer la experiencia y cuyo desgarro hay que sostener hasta el final, es la comprensión y el saber de que la ausencia de penuria es la suprema y la más oculta de las penurias [die Notlosigkeit die höchste und verborgenste Not ist] [...]

La ausencia de penuria consiste en creer que se tiene en las manos lo real [das Wirkliche] y la realidad [die Wirklichkeit] y que se sabe qué sobre todos los muertos que allá fenecieron" (Homero, Odisea. Trad. de E. Crespo y J. M. Pabón. Madrid, Espasa, 1999, XI, pp. 488-491).

${ }^{49}$ M. Heidegger, "Superación de la metafísica", en op. cit., p. 68

${ }^{50}$ Ibid., p. 72. 
es lo verdadero [das Wahre], sin que se necesite saber en qué esencia la verdad [worin die Wahrheit west]. ${ }^{51}$

La globalización es esa "ausencia de penuria y la más oculta de las penurias [Notlosigkeit und die verborgenste Not]", pues en ella y por ella, la realidad está presente como la cosa más comprensible y en todo caso como la cosa más visible. Quién duda que la realidad es hoy, más que nunca, lo más visible en todos los rincones del planeta. E incluso el planeta mismo es visible desde el espacio como "la esfera bien redonda" que no es. Y puesto que esto no va a cambiar: "El despliegue del dominio incondicionado de la metafísica no ha hecho más que empezar (steht erst an ihrem Beginn)", 52 el dolor que genera esta situación no va a hacer sino aumentar. Pero, ¿puede aún aumentar el olvido del dolor del mundo? ¿Podemos ocultarnos aún más la penuria y disfrutar de la imagen uniforme que nos ofrece el espectáculo global de las diferencias domesticadas, economizadas?

“¿Podrá tal vez [el exceso] de dolor [das Übermass an Leid] traer todavía un cambio?", se pregunta Heidegger al final de la Superación de la metafísica. ${ }^{53}$

Y qué cantidad de dolor podría acabar con el dolor mismo que es el olvido del dolor del mundo, en cuanto in-comprensión y no saber "que [es] la ausencia de penuria [...] la más oculta de las penurias". Pero este exceso (Übermass) de dolor, ¿es aún dolor o ya en su exceso ni siquiera se siente? Lo incalculable de ese dolor, su falta de medida, su imposibilidad de reducirse a los parámetros epistemológicos actualmente triunfantes, es desde donde se podría producir un cambio con relación al olvido del dolor del mundo, según Heidegger. Exceso que tiene que ver con el gigantismo que en el comienzo de este escrito atribuíamos a la globalización en la que estamos inmersos. Un gigantismo cuya esencia consiste en que la cantidad devenida cualidad propiciaría, como exceso de dolor, el cambio, al ser capaz de trascender la dimensión dolorosa del mundo en su pasividad óntica y así poder acceder al ámbito de su comprensión y su saber. De este modo, se justifica el surgimiento de una episteme hermenéutica ${ }^{54}$ capaz $^{4}$ de tratar con lo que sobrepasa las medidas que rigen el ámbito de lo epistemo-

${ }^{51}$ Ibid., p. 66.

52 Ibid., p. 56.

53 Ibid., p. 73.

${ }^{54} \mathrm{Si}$ los antecedentes de una episteme hermenéutica están en Schleiermacher y Dilthey, su planteamiento teórico contemporáneo pasa, entre otros, por Heidegger, Gadamer, Derrida o Ricoeur, que es quizá quien más ha trabajado la relación entre epistemología y hermenéutica con la intención de reconciliar ambas perspectivas siguiendo el leitmotiv de su pensamiento: "explicar más para comprender mejor, comprender mejor para explicar más". Vid. P. Ricoeur, Démythologisation et herméneutique, en Rudolf Bultmann, Nouveau Testament et Mythologie. Ginebra, Labor et Fides, 2013. 
lógico convencional, alentando una expectativa de conocimiento alternativa a la de las ciencias positivas, pero no por ello menos veraz, ${ }^{55}$ para tratar con la dimensión del ser que escapa a lo meramente racional de la metafísica, sin ser por ello irracional y absurdo. ${ }^{56}$ Una posibilidad de cambio vinculada a la posibilidad de acceso al fundamento de la metafísica: "Ahora bien, lo que sí es posible es que si algún día el pensar consigue retornar al fundamento de la metafísica ocasione un cambio [Wandel] en la esencia del hombre que llevaría aparejada una metamorfosis [Verwandlung] de la metafísica". ${ }^{57}$ Un retorno al fundamento de la metafísica que hoy en la era de la globalización está más lejos que nunca, si es que alguna vez estuvo cerca.

Porque si en el fundamento de la metafísica se encuentra el olvido del ser como olvido de la diferencia ontológica, su rememoración meditante está absolutamente fuera de la conexión global en la que estamos inmersos y a la que nos fuerza el economicismo ambiente. Hasta el punto de que en dicho fundamento se sitúe quizá el afuera mismo que posibilita la esfericidad de la tierra desde el espacio ya conquistado y siempre en expansión. Y de nuevo vemos cómo la metafísica nos tiene atrapados en su poder explicativo y fundamentador, imposibilitando el cambio. La única opción digna tras aceptar (verwinden) la insuperabilidad (Unüberwindlichkeit) de la metafísica es denunciar este escándalo epistemológico en la medida en que la ciencia, en lo que debe al pensar, no se interesa de manera suficiente por la problemática que plantea hoy la philosophía proté que es la episteme hermenéutica: escuchar a los poetas que nombrando lo sagrado ${ }^{58}$ propician el cambio, lo que no ocurre con la metafísica cuya extensión tecno-científica, gloria de la globalización, y su no pensar la esencia de la técnica, impide toda posibilidad de cambio en la dirección de un auténtico preguntar.

${ }^{55}$ Cf. Bernard Williams, Vérité et véracité. Essai de généalogie. Trad. de J. Lelaidier. París, Gallimard, 2006.

${ }^{56}$ Desde que Heidegger publicó Ser y tiempo en 1927, la hermenéutica filosófica ha ido ampliando su horizonte epistemológico hasta que su actividad científica está universalmente reconocida gracias a la obra de autores como el propio Heidegger, Gadamer, Ricoeur, Greisch, Vattimo, Rorty, y un largo etcétera cuya valía estriba en mantener vivo un modo de racionalidad que no se somete al imperio de la calculabilidad instrumental y que busca a través de usos del lenguaje pertinentes un pensar absolutamente atento a la esencia comprensiva (hermenéutica) del ser humano.

${ }^{57}$ M. Heidegger, "Introducción a ‘QQué es la metafísica?’”, en op. cit., p. 301.

58 " [...] el pensar y poetizar se igualan del modo más puro en su cuidado por la palabra, ambos se encuentran a un tiempo separados en su esencia del modo más distante. El pensador dice el ser. El poeta nombra lo sagrado" (M. Heidegger, "Introducción a ¿Qué es la metafísica?”, en op. cit., pp. 257-258). 


\section{Conclusión}

En ese sentido, la situación de exitosa penuria ${ }^{59}$ en la que nos encontramos por no escuchar la palabra de los poetas, queda descrita por Heidegger cuando escribe:

Desde todas partes, con ayuda de la sociología, de la psicología y del psicoanálisis, y todavía con algunos otros medios, [se procura] que todos los hombres queden dispuestos de igual manera en el mismo estado de una felicidad igual, y que se asegure la igualdad del bienestar de todos. Pero, a pesar de esta invención de la felicidad, los hombres son zarandeados de una guerra mundial a otra. ${ }^{60}$

Aunque hoy la guerra mundial no tiene lugar entre los viejos Estados-nación de Occidente, al menos en su cruda expresión militar, sino más bien en sus confines, y cuando la felicidad se presenta como la máxima aspiración de un humano normalizado por el consumo y el disfrute de la oferta global, ${ }^{61}$ los motivos para sospechar acerca de la benevolencia de la pax capitalista impuesta por el dominio neo-liberal son cada vez más evidentes. Pues el telos que persigue dicha pax no es generar las condiciones epistemológico-hermenéuticas para pensar el olvido del dolor del mundo, dando así inicio a su fin, sino el mero incremento del beneficio de la usura que a través de los accionistas justifica la actividad del capital en su dominio global. Todo esto nos aleja más si cabe,

59 "El tiempo de miseria, es el tiempo [nuestra historia, en adelante] de lo que Hölderlin llamaba también el dolor [Schmerz, aunque también Leiden], ese término que escande el poema En un azul amable y escande, de igual manera y no por casualidad, toda la lírica moderna, de Baudelaire a Trakl o a Mandelstam. El dolor, y no tanto el sufrimiento, es lo que alcanza y golpea el corazón, lo más íntimo del hombre, esa extrema profundidad en la que, en su casi absoluta singularidad [en su ab-soledad], el hombre -nunca sujeto- es pura espera de otro, esperanza de un diálogo, en una salida para la soledad" (Ph. Lacou-Labarthe, La poesía como experiencia, p. 40).

${ }^{60}$ M. Heidegger, ¿Qué significa pensar?, p. 54.

61 "Desde un punto de vista teórico diferente, [...] la teoría de la posmodernidad afirma una diferenciación gradual de estos niveles, en la que lo económico se vuelve gradualmente cultural, mientras que lo cultural se vuelve gradualmente económico. La sociedad de la imagen y la publicidad, sin duda, puede documentar la gradual transformación de las mercancías en imágenes libidinales de ellas mismas, es decir, en productos prácticamente culturales; mientras que la disolución de la alta cultura y la simultánea intensificación de la inversión en mercancías culturales masivas puede bastar para sugerir que, cualquiera haya sido el caso en etapas y momentos anteriores del capitalismo [...], hoy no hay enclaves, ni estéticos ni de ninguna clase, en los que no impere la forma mercancía" (Fedric Jameson, Valencias de la dialéctica. Trad. de M. López Seoane. Buenos Aires, Eterna Cadencia, 2013, p. 512). 
del propósito pensante desde el qué configurar las condiciones para un nuevo inicio atento a la palabra del poetizar. Pues sólo en las antípodas del capital y de la globalización es posible que la palabra del poeta se haga eco de la diferencia como voz del ser, en la medida en que "la poesía es fundación en palabra del ser [Dichtung ist worthafte Stiftung des Seins] ${ }^{6}{ }^{62}$ escribe Heidegger. Sólo bajo estas condiciones será posible una verdadera memoria del olvido del dolor del mundo, expresión óntico existencial de ese otro olvido que viene decidiendo el destino de Occidente desde la revelación por la diosa de Parménides del

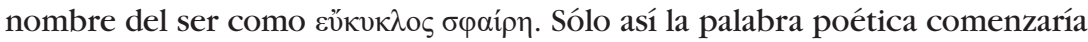
a desplegar en el "libre ofrecimiento" ${ }^{63}$ su esencia sagrada ${ }^{64}$ posibilitando el

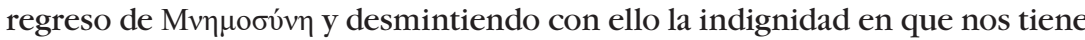
sumidos la triunfal globalización cuando por boca del poeta se nos acusa de que: "No damos muestras de dolor [Schmerzlos sind wir] [...]". 65

${ }^{62}$ M. Heidegger, "Hölderlin y la esencia de la poesía", en Aclaraciones a la poesía de Hölderlin. Trad. de H. Cortés y A. Leyte. Madrid, Alianza, 2005, p. 46.

${ }^{63}$ Idem.

${ }^{64}$ Vid. Beda Allemann, "La dimension du sacré", en Hölderlin et Heidegger. Trad. de F. Fédier. París, PUF, 1959, pp. 158 y ss.

${ }^{65}$ Hölderlin, Mnemosyne [Zweite Fassung], vv. 1-3, en M. Heidegger, ¿Qué significa pensar?, p. 55. 